\title{
Anti-diabetic activity and mineral elements evaluation of Vernonia amygdalina leaves obtained from Malaysia
}

\author{
Oluwaseun Ruth ALARA 1 * (D), Nour Hamid ABDURAHMAN 1 (D) \\ 1 Faculty of Chemical and Natural Resources Engineering, Universiti Malaysia Pahang, Lebuhraya Tun Razak, 26300, \\ Gambang, Malaysia. \\ * Corresponding Author. E-mail: ruthoalao@gmail.com (O.R.A.); Tel. +60-111-654 3727.
}

Received: 24 December 2018 / Revised: 07 February 2019 / Accepted: 10 February 2019

\begin{abstract}
Diabetes has been characterized by transmuted lipids, hyperglycemia, proteins, and carbohydrates metabolism that can affect the quality of life. Although there are quite several synthetic drugs used in managing this disease, however, due to their side effects, the use of natural sources is imperative. This study focused on the in-vitro inhibitory activity of Vernonia amygdalina leaf grown in Malaysia using both a-amylase and a-glucosidase assays. The quantities of mineral elements in the plant extracts through microwave-assisted and Soxhlet extraction methods were as well examined through inductively coupled plasma mass spectrometry (ICP-MS) analysis. The extract of $V$. amygdalina leaf showed the highest dose-dependent effect of 97.28 and $98.08 \%$ of inhibition at $1.0 \mathrm{mg} / \mathrm{mL}$ having $\mathrm{IC}_{50}$ values of $0.51 \mathrm{mg} / \mathrm{mL}$ and $0.49 \mathrm{mg} / \mathrm{mL}$ against a-amylase and a-glucosidase enzymes, respectively. The inhibitory effects of the extract were higher than acarbose (a standard drug). Moreover, the results showed that higher quantities of mineral elements (potassium, magnesium, and calcium) and a lesser quantity of chromium in the extracts through microwave-assisted extraction (MAE) indicate that the technique possesses a higher capacity in obtaining higher mineral nutrients over Soxhlet extraction and more anti-diabetic activity of the extract. Thus, the extract exhibited an effective anti-diabetic activity which implies that it potentially serves as a natural source for managing diabetes.
\end{abstract}

KEYWORDS: Mineral elements; Vernonia amygdalina; anti-diabetic activity; alpha-amylase; alpha-glucosidase.

\section{INTRODUCTION}

In the ancient times, plants were commonly used in the treatment of several infectious ailments. Nowadays, more attention is being given to the consumption of herbal medicine instead of synthesis drugs due to the reported adverse effects from synthetic medicine to the human system. Over the years, Diabetes mellitus has been the main health challenge worldwide. About 350 million people had been forecasted to suffer this syndrome by 2030 [1]. It is a chronic syndrome distinguished through increased blood glucose levels which are associated with carbohydrate, proteins and proteins metabolism [2]. The key source of glucose in a body system is the hydrolysis of dietary starch where alpha-glucosidase and alpha-amylase being the pitch enzymes required in breaking down of intestinal absorption and starch, respectively [1]. Studies had shown that the inhibitory effects of these enzymes can slow down the digestion of carbohydrate resulting in the reduction of post-prandial serum glucose level and its absorption, thus, it can be a key method of managing hyperglycemia which is closely related to type II diabetes [2,3]. Although, there are several synthetic drugs used in managing this disease which include acarbose, voglibose and miglitol, however, side-effects such as bloating, liver disorder, flatulence, abdominal discomfort, and diarrhoea which can reduce the effectiveness of the drugs have been reported [4]. Consumptions of vegetables and fruits play essential roles in human diets because they can replenish the human body with proteins, vitamins, energy, and minerals [5]. Therefore, search for the alternative, non-toxic and effective inhibitors from natural sources continued to be an essential part of the study.

Vernonia amygdalina leaf is part of Vernonia genus with outstanding benefit to human diets. It belongs to the family Asteraceae which comprises about 1000 species worldwide [6]. This plant has been traditionally used as an indispensable medicinal plant for ages particularly amidst sub-Saharan Africans to treat malaria, stomach disorder, hiccups, diabetes, inflammation, fertility problem, bacterial infections, and among others [7]. This species is endowed with fats, proteins, fibres, minerals, amino acids, carbohydrate, and vitamins [8,

How to cite this article: Alara OR, Abdurahman NH. Anti-diabetic activity and mineral elements evaluation of Vernonia amygdalina leaves obtained from Malaysia. J Res Pharm. 2019; 23(3): 514-521. 
9]. Studies from several parts of the world had observed that $V$. amygdalina leaf extracts are a promising glucose inhibitor [10-13]. However, a report had shown that geographical location can affect the yields and bioactivity of plant extracts [14]. $V$. amygdalina has been identified as one of the medicinal plants used traditionally in Malaysia [15].

Moreover, the food chain can be affected by the consumption of heavy metals generated from the environment. This can be through soil pollution due to the usage of pesticides, disposal of chemical effluents, chemical fertilizer, and irrigation water [16]. Therefore, it is important to examine the mineral contents in the herbal substances for food safety. Inductively coupled plasma mass spectrometry (ICP-MS) is one of the efficient techniques for quantitatively and qualitatively detect trace elements in a sample. ICP-MS is virtually used in every discipline where inorganic analytical is needed, namely biological, environmental, nuclear, medical, nutritional, and metallurgical studies. The main importance of ICP-MS is that accurate and error-free result can be achieved using isotope-dilution mass spectrometry. It has the multi-elemental ability, low detection limits, long linear dynamic, rapid isotopic analysis, and good precision [17].

Therefore, this study focused on the in vitro anti-diabetic activity and mineral elements in the extracts from $V$. amygdalina leaves grown in Malaysia through Soxhlet extraction and microwave-assisted extraction (MAE) methods.

\section{RESULTS AND DISCUSSION}

\subsection{In vitro anti-diabetic inhibitory activity}

Reduction in the blood glucose level is an important way of controlling diabetes issues. Most especially, oral hypoglycemic drugs are used as inhibitors of saccharide-hydrolyzing enzymes (alpha-amylase and amylase-glucosidase) for type II diabetes. Carbohydrate digestion and elongated digestion time are being delayed through the inhibitions of these enzymes, resulting in the reduction of glucose absorption rate and postprandial plasma glucose [18]. The inhibitory activity of $V$. amygdalina leaf extract against alpha-amylase enzyme is illustrated in Fig. 1a. This result showed that the extract inhibited alpha-amylase in a dose-dependent pattern $(0.2-1.0 \mathrm{mg} / \mathrm{mL})$. The highest and lowest inhibitory activities of the extract were recorded at concentrations of 0.2 and $1.0 \mathrm{mg} / \mathrm{mL}$, respectively. There were significant differences between the extracts using optimized MAE and Soxhlet extraction technique, whereby the extracts obtained through optimized MAE showed the highest activity. The lower activities of extracts from Soxhlet extraction might be attributed to the influence of localized heating generated from this method at longer extraction time which can cause a degradation in the phenolic compounds responsible for this activity [19].

As compared with a standard drug (acarbose) in the same concentration, it can be observed the extract exhibited higher activity compared to the drug which shows the potential inhibitory activity of $V$. amygdalina leaf grows in Malaysia. However, the $\mathrm{IC}_{50}$ value (Concentration of the extract at $50 \%$ inhibitory activity) of $V$. amygdalina leaf extract was $0.51 \mathrm{mg} / \mathrm{mL}$ which is lower to that of acarbose $(0.56 \mathrm{mg} / \mathrm{mL})$, indicating higher inhibitory activity of the extract. In a similar, the IC $\mathrm{I}_{50}$ value of $8.4 \mu \mathrm{g} / \mathrm{mL}$ and $10.6 \mu \mathrm{g} / \mathrm{mL}$ have been reported for both free and bound phenol extract from $V$. amygdalina leaf grown in Nigeria [20]. Natural polyphenols have been reported to inhibit the activity of carbohydrate hydrolysing enzymes [21]. This obtained result has displayed the potential use of an extract from $V$. amygdalina leaf in managing type II diabetes.

Alpha-glucosidase inhibitors have been grouped to be the third category of hypoglycemic agents [22]. The result obtained for in-vitro alpha-glucosidase inhibition of $V$. amygdalina leaf extract is presented in Fig. $1 \mathrm{~b}$. The result showed that the extract exhibited a strong inhibitory effect against alpha-glucosidase enzyme with the higher activity at a dose-dependent of $1.0 \mathrm{mg} / \mathrm{mL}$. Like result obtained for alpha-amylase inhibition, the extract obtained through optimized MAE showed higher efficiency compared to acarbose against alphaglucosidase enzyme with the $\mathrm{IC}_{50}$ values of $0.49 \mathrm{mg} / \mathrm{mL}$ and $0.54 \mathrm{mg} / \mathrm{mL}$, respectively. In contrast, the extract obtained through a Soxhlet extraction technique showed lower activity compare to acarbose with an $\mathrm{IC}_{50}$ value of $0.70 \mathrm{mg} / \mathrm{mL}$. This simply means that active components of $V$. amygdalina leaf extract compete with the substrate in binding to the active site of an alpha-glucosidase enzyme, thus, prevent the breakdown of oligosaccharides to disaccharides [23]. A similar report had been given by Pandithurai et al. whereby the methanolic extract of Spatoglossum asperum showed higher inhibition of $900 \mu \mathrm{g} / \mathrm{mL}$ concentration inhibited alpha-glucosidase enzyme by $96.75 \%$ compared to the results of this study [24]. Nevertheless, V. amygdalina leaf also showed higher inhibition effect. This might be due to the presence of higher contents of secondary metabolites in the extract of $V$. amygdalina leaf as earlier reported [25]. Therefore, the extract from $V$. amygdalina leaf has potential in managing type II diabetes. 
The strong inhibitory effect of extracts from $V$. amygdalina leaves supports the findings of Nwanjo where it was reported that the extracts reduced the blood glucose, increased the serum triglyceride levels and serum MDA, increased the LDL-cholesterol, and normalized cholesterol concentrations in streptozocin-induced diabetic rats [26]. In another study on the effect of $V$. amygdalina leaves extracts on blood glucose of diabetic rats, the results showed that decrease in blood glucose after administration of the extracts may be associated with the presence vitamins, phytochemicals, and other nutrients in the extracts [27, 28]. Thus, the presence of trigonelline and caffeoylquinic acid derivative might be attributed to the anti-diabetic activity of the extracts $[29,30]$.
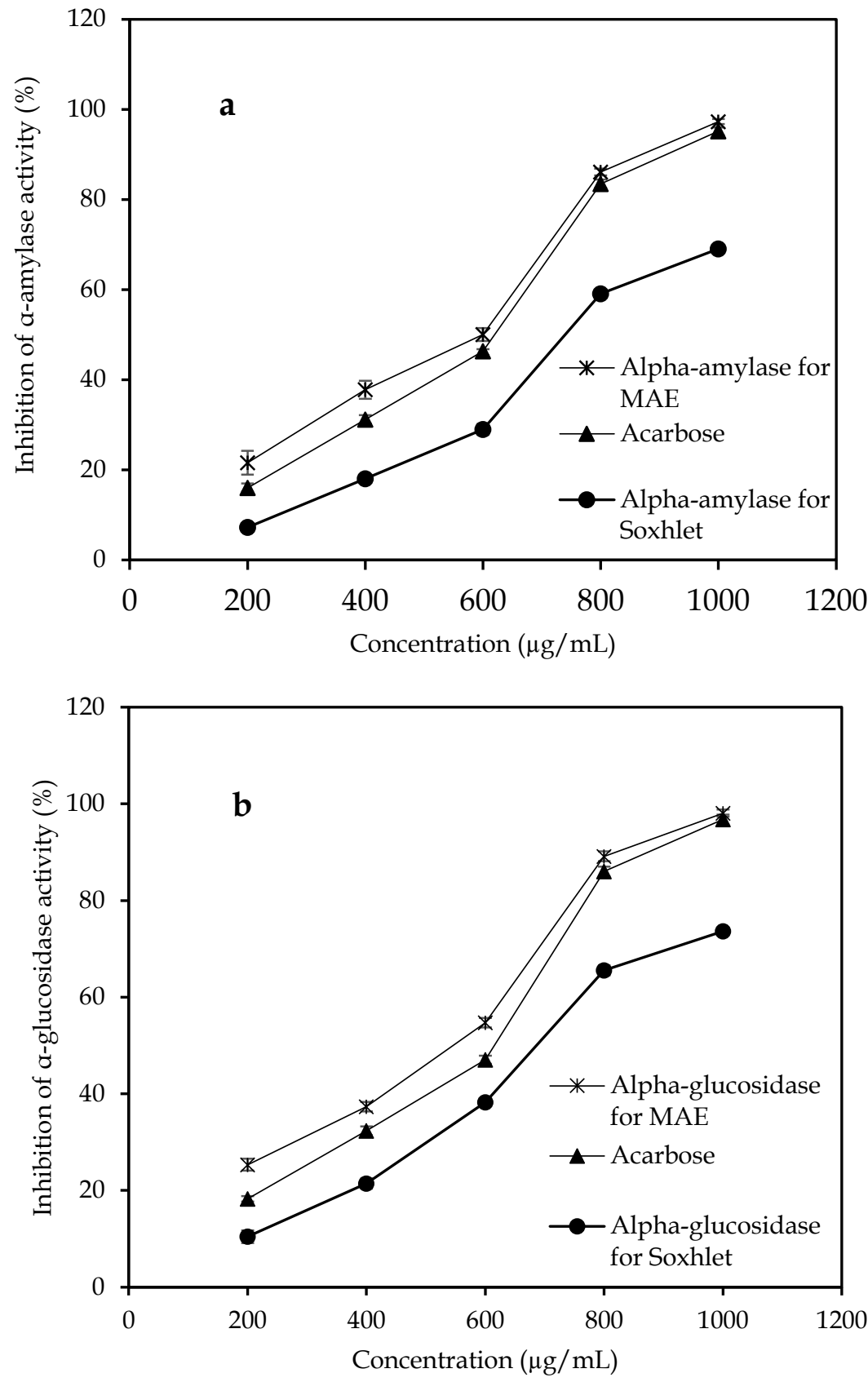

Figure 1. Anti-diabetic effect of extracts from V. amygdalina leaves against a-amylase enzyme (a) and against a-glucosidase enzyme (b).

\subsection{Elemental analysis of the extracts}

The results obtained for mineral elements in the extracts from $V$. amygdalina leaves using MAE (at optimized conditions) and Soxhlet extraction is shown in Table 1. Concentrations of twenty-two mineral 
elements which include magnesium, sodium, potassium, chromium, calcium, manganese, copper, iron, zinc, selenium, lead, cadmium, beryllium, aluminium, cobalt, vanadium, nickel, molybdenum, silver, antimony, and barium have been examined using an inductively coupled plasma mass spectrometers (ICP-MS). The presence or absence of these elements in the plant extracts might be responsible for their potential in curing several diseases [31].

Table 1. Mineral analysis of optimized MAE and Soxhlet extracts from $V$. amygdalina leaves.

\begin{tabular}{|c|c|c|c|c|}
\hline \multirow[t]{2}{*}{ S/N } & \multirow[t]{2}{*}{ Mineral element } & \multirow[t]{2}{*}{ Unit } & \multicolumn{2}{|c|}{ V. amygdalina leaves } \\
\hline & & & MAE & Soxhlet \\
\hline 1 & Sodium $(\mathrm{Na})$ & ppm & ND & ND \\
\hline 2 & Magnesium (Mg) & ppm & 35.5 & 10.2 \\
\hline 3 & Potassium $(\mathrm{K})$ & ppm & 1699.8 & 543.2 \\
\hline 4 & Calcium (Ca) & ppm & 10.0 & 4.1 \\
\hline 5 & Chromium $(\mathrm{Cr})$ & $\mathrm{ppb}$ & 25.6 & 32.5 \\
\hline 6 & Manganese (Mn) & ppb & ND & ND \\
\hline 7 & Iron $(\mathrm{Fe})$ & ppm & ND & ND \\
\hline 8 & Copper (Cu) & $\mathrm{ppb}$ & ND & ND \\
\hline 9 & Zinc $(\mathrm{Zn})$ & $\mathrm{ppb}$ & ND & ND \\
\hline 10 & Arsenic (As) & $\mathrm{ppb}$ & ND & ND \\
\hline 11 & Selenium (Se) & ppb & ND & ND \\
\hline 12 & Cadmium (Cd) & $\mathrm{ppb}$ & ND & ND \\
\hline 13 & Lead $(\mathrm{Pb})$ & $\mathrm{ppb}$ & ND & ND \\
\hline 14 & Beryllium (Be) & $\mathrm{ppb}$ & ND & ND \\
\hline 15 & Aluminium (Al) & $\mathrm{ppb}$ & ND & ND \\
\hline 16 & Cobalt (Co) & ppb & ND & ND \\
\hline 17 & Vanadium (V) & $\mathrm{ppb}$ & ND & ND \\
\hline 18 & Nickel (Ni) & ppb & ND & ND \\
\hline 19 & Molybdenum (Mo) & $\mathrm{ppb}$ & ND & ND \\
\hline 20 & Silver $(\mathrm{Ag})$ & $\mathrm{ppb}$ & ND & ND \\
\hline 21 & Antimony (Sb) & $\mathrm{ppb}$ & ND & ND \\
\hline 22 & Barium $(\mathrm{Ba})$ & $\mathrm{ppb}$ & ND & ND \\
\hline
\end{tabular}

* ND implies mineral element that is not detected in the extract since the value is less than $0.1 \mathrm{ppm} / \mathrm{ppb}$.

Amongst all these mineral elements, potassium was present in higher amount while magnesium, calcium and chromium were in moderate concentrations. In contrary, other considered mineral elements were present in trace quantities (below detection limit). In general, the extracts from both plant samples and extraction methods showed a wide variability. Moreover, the concentrations of potassium, magnesium and calcium in the extracts obtained through Soxhlet extraction were lower than that in optimized MAE, this might be attributed to the influence of localized heating generated from Soxhlet extraction that might have caused degradation of phytochemicals in the extracts. However, the chromium concentrations in the extracts from Soxhlet extraction were higher than that in optimized MAE. Chromium is a metallic element that the human body requires a very little amount. It is an indispensable portion of metabolic processes that control blood sugar level and assists the transportation of glucose through into cells, where it can be useful as energy (antidiabetic activity). In addition, chromium appears to be involved in the metabolism of carbohydrate, fat and protein [32]. The presence of this mineral element shows the anti-diabetic activity of both samples as the concentrations were below $50 \mathrm{ppb}$ as stated by Environmental Scientific Perspectives [33].

The potassium and calcium concentrations in the extracts from $V$. amygdalina leaves showed their potent in muscle contraction and synthesis of some protein. In addition, calcium helps in blood clotting, teeth and bone development, regulate heart rhythm, and lower blood pressure. Potassium aids the synthesis of metalloproteinase, lipoproteins, nucleoproteins, and chromoproteins that help the contraction of muscles. In addition, magnesium enhances the conversion of excess blood glucose to energy and reduce the level of cholesterol [34]. The presence of an appreciable amount of potassium, magnesium, calcium, and chromium in the extracts through MAE affirmed the advantage over Soxhlet extraction. Thus, it can be deduced that the MAE technique possesses a higher capacity to extract more nutrients from both plant samples compared to Soxhlet extraction. Therefore, the extracts from $V$. amygdalina leaves using optimized MAE can be potentially used for pharmaceutical and therapeutic purposes. 


\section{CONCLUSION}

This finding investigated the in vitro anti-diabetic activity of $V$. amygdalina leaf against a-amylase and a-glucosidase enzymes and quantities of 22 selected mineral elements in the extract of $V$. amygdalina leaf comparing MAE and Soxhlet extraction. The obtained results showed that extract possessed the higher inhibitory activity with $\mathrm{IC}_{50}$ values of $0.51 \mathrm{mg} / \mathrm{mL}$ and $0.49 \mathrm{mg} / \mathrm{mL}$ of alpha-amylase and alpha-glucosidase enzymes using MAE, respectively as compared to Soxhlet extraction technique. Moreover, the result obtained showed that more mineral elements (potassium, magnesium, and calcium) and a lesser quantity of chromium in the extracts through MAE showed that the technique possesses a higher capacity in obtaining higher mineral nutrients over Soxhlet extraction. The presence of these mineral elements showed that the extract possessed anti-diabetic activity. Thus, the extract obtained through MAE of $V$. amygdalina leaves can be a potential treatment for different ailments.

\section{MATERIALS AND METHODS}

\subsection{Collections of plant samples and preparation of extracts}

The plant samples used in this study (V. amygdalina leaves) were collected from Gambang, Malaysia. After the leaves were washed in water to eliminate dirt, dried at room temperature until the stable dry weight was achieved. The leaves were then ground and screened through an average particle size of $105 \mu \mathrm{m}$ mesh. Then, the samples were extracted using both MAE and Soxhlet extraction techniques.

The MAE was performed based on optimal conditions obtained in the previous studies [25]. The powdered sample of $V$. amygdalina leaves $(5 \mathrm{~g})$ was extracted for $4 \mathrm{~min}$ using a $50 \mathrm{~mL}$ of aqueous ethanol $(76 \%$ $\mathrm{v} / \mathrm{v}$ of ethanol concentration) at $70^{\circ} \mathrm{C}$ with microwave power set to $558 \mathrm{~W}$. Preceding individual experimental trial, the extract was filtered and concentrated using a rotary evaporator under vacuum at $50{ }^{\circ} \mathrm{C}$. The experimental process was repeated thrice, and the plant extracts were kept in a $4{ }^{\circ} \mathrm{C}$ refrigerator prior analyses.

For the Soxhlet extraction, $10 \mathrm{~g}$ weighed sample of $\mathrm{V}$. amygdalina leaves was loaded into a thimble placed in the Soxhlet extractor and $200 \mathrm{~mL}$ of aqueous ethanol $(76 \% \mathrm{v} / \mathrm{v}$ ethanol) was added into a round-bottom flask which was attached to the Soxhlet extractor equipped with a condenser (BST/SXM-6A, Delhi) on a mantle heater. The experiment was carried out for $2 \mathrm{~h}$ before the mixture could cool down to room temperature. The mixture was filtered and concentrated using a rotary evaporator. Thereafter, the experimental process was repeated thrice, and the plant extracts were kept in a $4{ }^{\circ} \mathrm{C}$ refrigerator prior analyses.

\subsection{In vitro anti-diabetic activities}

\subsubsection{Procedure for the alpha-amylase inhibitory assay}

The extract of $V$. amygdalina leaf was investigated for its anti-diabetic activity using a-amylase inhibitory assay according to the method described in the previous study by [35]. In brief, a mixture of $0.5 \mathrm{~mL}$ extract or acarbose at different concentration $(200-1000 \mu \mathrm{g} / \mathrm{mL}), 0.5 \mathrm{~mL}$ of $20 \mathrm{mM}$ sodium phosphate buffer ( $\mathrm{pH}$ of 6.9) and $0.5 \mathrm{~mL}$ of $0.5 \mathrm{mM}$ procaine pancreas alpha-amylase solution was pre-incubated for $10 \mathrm{~min}$ at room temperature. Thereafter, $0.5 \mathrm{~mL}$ of $1 \%$ starch dissolved in $20 \mathrm{mM}$ sodium phosphate buffer solution was mixed to the mixture after pre-incubation. Dinitrosalicylic (DNS) acid colour reagent of $1.0 \mathrm{~mL}$ was then added to the mixture to terminate the reaction. The mixture was left to incubate for $5 \mathrm{~min}$ in a water bath operated at $90{ }^{\circ} \mathrm{C}$ and allowed to cool down before diluting the mixture with $5 \mathrm{~mL}$ of distilled water. Then, the absorbance at $540 \mathrm{~nm}$ was recorded using a UV-Vis Spectrophotometer. The a-amylase inhibitory activity was evaluated using (Eq. 1) by comparing the readings from the sample mixture with control (a mixture of alpha-amylase solution and sodium phosphate buffer). The blank was sodium phosphate buffer.

Alpha-amylase inhibition $=\frac{A_{\text {control }}-A_{\text {sample }}}{A_{\text {control }}} \times 100 \%$

where $\mathrm{A}_{\text {control }}$ represents alpha-amylase and phosphate buffer solution mixture; and $\mathrm{A}_{\text {sample }}$ denotes alphaamylase solution, phosphate buffer, and sample extract mixture.

\subsubsection{Procedure for the alpha-glucosidase inhibitory assay}

The alpha-glucosidase inhibitory capacity of extract from $V$. amygdalina leaf was observed according to the procedure explained by [35]. In brief, a mixture of $0.05 \mathrm{~mL}$ extract or acarbose at different concentration $(200-1000 \mu \mathrm{g} / \mathrm{mL})$ and $0.1 \mathrm{~mL}$ of $1.0 \mathrm{U} / \mathrm{mL}$ alpha-glucosidase solution was pre-incubated at room temperature 
for $10 \mathrm{~min}$. Afterwards, $0.05 \mathrm{~mL}$ of $3.0 \mathrm{mM}$ p-nitrophenyl glucopyranoside dissolved in $20 \mathrm{mM}$ phosphate buffer ( $\mathrm{pH}$ of 6.9) was mixed with the mixture. Then, the mixture was incubated for $20 \mathrm{~min}$ at $37{ }^{\circ} \mathrm{C}$ and the reaction was ended through the addition of $0.5 \mathrm{~mL}$ of $100 \mu \mathrm{M}$ sodium carbonate. Then, the absorbance was read at $405 \mathrm{~nm}$ using a UV-Vis Spectrophotometer. The alpha-glucosidase inhibition was evaluated using (Eq. 2) by comparing the readings from the sample mixture with control (a mixture of alpha-glucosidase solution and phosphate buffer). The blank was phosphate buffer.

Alpha-glucosidase inhibition $=\frac{A_{\text {control }}-A_{\text {sample }}}{A_{\text {control }}} \times 100 \%$

where $\mathrm{A}_{\text {control }}$ represents alpha-glucosidase and phosphate buffer solution mixture; and $\mathrm{A}_{\text {sample }}$ denotes the alpha-glucosidase solution, phosphate buffer, and sample extract mixture.

\subsection{ICP-MS analysis of the plant extracts}

The quantities of mineral elements (K, Na, Mg, Mn, $\mathrm{Cr}, \mathrm{Ca}, \mathrm{Zn}, \mathrm{Fe}, \mathrm{As}, \mathrm{Cu}, \mathrm{Cd}, \mathrm{Se}, \mathrm{Be}, \mathrm{Al}, \mathrm{Co}, \mathrm{V}, \mathrm{Pb}, \mathrm{Ni}$, $\mathrm{Mo}, \mathrm{Ag}, \mathrm{Sb}$, and $\mathrm{Ba}$ ) in $\mathrm{V}$. amygdalina leaf extracts for both MAE and Soxhlet method were determined using Inductively Coupled Plasma-Mass Spectrometry (ICP-MS 7500, Agilent, US) analysis. The methodology described in a previous study was employed [16]. In brief, calibration solution was prepared using the multielement standard solution from which the concentration ranging from 0-50 ppm of standard solution was utilized to prepare a calibration curve, the blank was taken to be $2 \%$ of nitric acid $\left(\mathrm{HNO}_{3}\right)$. The aqueous plant extract was injected into the ICP-MS nebulizer and spray chamber. Then, the extract was dried, atomized, ionized, and vaporized, within the plasma chamber containing varied heating zones. The compositions of mineral elements in the plant samples were acquired from the transfiguration of the aqueous plant sample into positively charged ions and excited atoms.

Acknowledgements: The authors acknowledge Universiti Malaysia Pahang for financial support through RDU180329.

Author contributions: Concept - O.R.A, N.H.A.; Design - O.R.A, N.H.A.; Supervision - N.H.A.; Resource - N.H.A.; Materials - O.R.A, N.H.A.; Data Collection \&/or Processing - O.R.A.; Analysis \&/or Interpretation - O.R.A.; Literature Search - O.R.A.; Writing - O.R.A.; Critical Reviews - O.R.A, N.H.A.

Conflict of interest statement: We declare no conflict of interest.

\section{REFERENCES}

[1] Mohanapriya N, Murugesan S, Sivamurugan V. In vitro a-amylase and a-glucosidase inhibitory activity of methanol extract of Tolypiocladia glomerulata (C. Agardh) F. Saudi J Biomed Res. 2016;1:59-63. [CrossRef]

[2] Gomathi D, Kalaiselvi M, Uma C. In vitro a-amylase and a-glucosidase inhibitory effects of ethanolic extract of Evolvulus alsinoides (L.). Int Res J Pharm. 2012;3:226-229.

[3] Wickramaratne MN, Punchihewa JC, Wickramaratne DBM. In-vitro alpha amylase inhibitory activity of the leaf extracts of Adenanthera pavonina. BMC Complement Altern Med. 2016;16:1-5. [CrossRef]

[4] Selvaraj IC. In vitro investigation of antidiabetic potential of selected traditional medicinal plants. Int J Pharmacogn Phytochem Res. 2014;6:856-861.

[5] Cheynier V. Phenolic compounds: From plants to foods. Phytochem Rev. 2012;11:153-177. [CrossRef]

[6] Toyang NJ, Verpoorte R. A review of the medicinal potentials of plants of the genus Vernonia (Asteraceae). J Ethnopharmacol. 2013;146 681-723. [CrossRef]

[7] Alara OR, Abdurahman NH, Abdul Mudalip SK, Olalere OA. Phytochemical and pharmacological properties of Vernonia amygdalina: A review. J Chem Eng Ind Biotechnol. 2017;2:80-96. [CrossRef]

[8] Audu SA, Alemika ET, Abdulraheem RO, Abdulkareem SS, Abdulraheem RB, Ilyas M. A study review of documented phytochemistry of Vernonia amygdalina (Family Asteraceae) as the basis for pharmacologic activity of plant extract. J Nat Sci Res. 2012;2:1-9.

[9] Lakshmi Prabha J. Therapeutic uses of Vernonia cinerea - A short review. Int J Pharm Clin Res. 2015;7:323-325.

[10] Erasto P, van de Venter M, Roux S, Grierson DS, Afolayan AJ. Effect of leaf extracts of Vernonia amygdalina on glucose utilization in chang-liver, $\mathrm{C}_{2} \mathrm{C}_{12}$ muscle and 3T3-L1 cells. Pharm Biol. 2009;47(2):175-181. 
[11] Owen TA, Amakiri OJ, Karibi-Botoye AO. Sugar-lowering effects of bitter leaf (Vernonia amygdalina) in experimental broiler finisher chickens. Asian J Pharm Clin Res. 2011;4:19-21.

[12] Erasto P, Grierson DS, Afolayan AJ. Evaluation of antioxidant activity and the fatty acid profile of the leaves of Vernonia amygdalina growing in South Africa. Food Chem. 2007;104:636-642. [CrossRef]

[13] Atangwho IJ, Egbung GE, Ahmad M, Yam MF, Asmawi MZ. Antioxidant versus anti-diabetic properties of leaves from Vernonia amygdalina Del. growing in Malaysia. Food Chem. 2013;141:3428-3434. [CrossRef]

[14] Muraina I, Adaudi A, Mamman M, Kazeem H, Eloff J. Effects of geographical location on the yield and bioactivity of Anoigeissus leiocarpus. J Pharm Bioresour. 2010;5(2):68-72. [CrossRef]

[15] Razak MRMA, Afzan A, Ali R, Jalaluddin NFA, Wasiman MI, Zahari SHS, Abdullah NR, Ismail Z. Effect of selected local medicinal plants on the asexual blood stage of chloroquine resistant Plasmodium falciparum. BMC Complement Altern Med. 2014;14:1-13. [CrossRef]

[16] Hajar EWI, Sulaiman AZ, Sakinah AMM. Assessment of Heavy metals tolerance in leaves, stems and flowers of Stevia rebaudiana plant. Procedia Environ Sci. 2014;20:386-393. [CrossRef]

[17] Howard ET. Inductively coupled plasma-mass spectrometry, Academic Press, Unites State of America, 2001.

[18] Tundis R, Loizzo MR, Menichini F. Natural Products as a-amylase and a-glucosidase inhibitors and their hypoglycaemic potential in the treatment of diabetes: An update. Mini-Reviews Med Chem. 2010;10:315-331. [CrossRef]

[19] Shams KA, Abdel-azim NS, Saleh IA, Hegazy MF, El-missiry MM, Hammouda FM, Bohouth E, Tahrir E. Green technology: Economically and environmentally innovative methods for extraction of medicinal \& aromatic plants (MAP) in Egypt. J Chem Pharm Res. 2015;7:1050-1074.

[20] Saliu JA, Ademiluyi AO, Akinyemi AJ, Oboh G. In vitro antidiabetes and antihypertension properties of phenolic extracts from bitter leaf (Vernonia amygdalina del.). J Food Biochem. 2012;36:569-576. [CrossRef]

[21] Uddin N, Hasan MR, Hossain MM, Sarker A, Hasan AHMN, Islam AFMM, Chowdhury MMH, Rana MS. In vitro aamylase inhibitory activity and in vivo hypoglycemic effect of methanol extract of Citrus macroptera Montr. fruit. Asian Pac J Trop Biomed. 2014;4:473-479. [CrossRef]

[22] Yin Z, Zhang W, Feng F, Zhang Y, Kang W. a-Glucosidase inhibitors isolated from medicinal plants. Food Sci Hum Wellness. 2014;3:136-174. [CrossRef]

[23] Kazeem MI, Ogunbiyi JV, Ashafa AOT. In vitro studies on the inhibition of alpha-amylase and alpha-glucosidase by leaf extracts of Picralima nitida (Stapf). Trop J Pharm Res. 2013;12:719-725. [CrossRef]

[24] Pandithurai M, Murugesan S, Bhuvaneswari S, Thennarasan S. In vitro a-amylase and a-glucosidase inhibition activity of methanolic extract of marine brown alga Spatoglossum asperum. Int J Adv Pharm. 2015;5:83-87. [CrossRef]

[25] Alara OR, Abdurahman NH, Olalere OA. Ethanolic extraction of bioactive compounds from Vernonia amygdalina leaf using response surface methodology as an optimization tool. J Food Meas Charact. 2018;12:1107-1122. [CrossRef]

[26] Nwanjo HU. Efficacy of aqueous leaf extract of Vernonia amygdalina on plasma lipoprotein and oxidative status in diabetic rat models. Niger J Physiol Sci. 2005;20:39-42.

[27] Nwaoguikpe RN. The effect of extract of bitter leaf (Vernonia amygdalina) on blood glucose levels of diabetic rats. Int J Biol Chem Sci. 2010;4:721-729.

[28] Ejike CECC, Awazie SO, Nwangozi PA, Godwin CD. Synergistic postprandial blood glucose modulatory properties of Vernonia amygdalina (Del.), Gongronema latifolium (Benth.) and Occimum gratissimum (Linn.) aqueous decoctions. J Ethnopharmacol. 2013;149:111-116. [CrossRef]

[29] Alara OR, Abdurahman NH, Ukaegbu CI, Hassan Z, Kabbashi, NA. Dataset on LC-Q-TOF/MS tentative identification of phytochemicals in the extract of Vernonia amygdalina leaf through positive ionization. Data in Brief. 2018;21:1686-1689. [CrossRef]

[30] Folwarczna J, Janas A, Pytlik M, Sliwi L. Effects of trigonelline, an alkaloid present in coffee. Nutrients. 2016;8:1-12. [CrossRef]

[31] Mushtaq T, Bahadur A, Shah Z, Danish M, Khalid S. Elemental and nutritional analysis and ethnomedicinal study of selected wild plants species of District Swabi, Khyber Pakhtunkhwa, Pakistan. J Pharm Res. 2012;5:4910-4913.

[32] Pechova A, Pavlata L. Chromium as an essential nutrient: A review. Vet Med (Praha). 2007;52:1-18. [CrossRef]

[33] Krejpcio Z. Essentiality of chromium for human nutrition and health. Endocr Rev. 2001;10:399-404. 
[34] Ragavendran P, Sophia ARCD, Starlin T, Gopalakrishnan VK. Elemental analysis of Aerva lanata (L.) by EDX method. Int Res J Pharm. 2012;3:218-220.

[35] Alara OR, Abdurahman NH, Ukaegbu CI, Azhari NH. Vernonia cinerea leaves as the source of phenolic compounds, antioxidants, and anti-diabetic activity using microwave-assisted extraction technique. Ind Crop Prod. 2018;122:533544. [CrossRef]

This is an open access article which is publicly available on our journal's website under Institutional Repository at http://dspace.marmara.edu.tr. 